\title{
PENYELESAIAN SENGKETA EKONOMI ISLAM BERBASISKAN NILAI KEPASTIAN HUKUM
}

\author{
Misbahul Huda \\ Dosen Institute of Business Law and Legal Management \\ ABSRAK
}

Ekonomi islam sebagai salah satu instrumen ekonomi indonesia telah menwarkan sebuah sistem yang tepat bagi keberlangsungan ekonomi nasional. Namun dalam praktiknya, sistem ekonomi islam mestinya masih perlu dilakukan perbaikan yang salah satunya dalam sistem penyelesaian sengket. Selama ini dalam praktinya sesuai dengan perundang-undangan penyelesaian sengketa dilakukan oleh pengadilan agama, akan tetap masih terbukanya peluang dalam penyelesaian segketa melalui pengadilan negeri telah membuka peluang besar bagi terciptanya ketidakpastian hukum. Disinilah perlunya mahkamah agung memberikan penegasan yang berkaitan hal-hal masalah sengketa ekonomi islam diselesaikan melalui pengadilan agam dan secara khusus kewenangan tersebut bersifat mutlak sehingga nilai penyelesaian sengketa ekonomi islam nantinya dapat berbasiskan nilai kepastian hukum.

Keyword : sengketa, ekonomi islam dan kepastian hukum.

\section{ISLAMIC ECONOMIC DISPUTE SETTLEMENT BASED ON THE VALUE OF LEGAL DEFINITION

\author{
Misbahul Huda \\ Lecture Institute of Business Law and Legal Management
}

\begin{abstract}
Islamic economics as one of the economic instruments in Indonesia has offered a system that is right for the sustainability of national economy. But in practice, the Islamic economic system should still need to be repaired, one of them is in the system of settlement of clutch. So far, in practice in accordance with the dispute resolution legislation carried out by religious courts, there is open opportunities in the dispute settlement through the district court. It has opened up great opportunities for the creation of legal uncertainty. This is where the necessity of the Supreme Court to provide affirmations related to issues of economic disputes of Islam. It is resolved through religious courts and specifically the authority is absolute, so that the value of Islamic economic dispute resolution will be based on the value of legal certainty.
\end{abstract}

Keyword: dispute, Islamic economy and legal certainty. 


\section{LATAR BELAKANG}

Lahirnya Undang-Undang Nomor 21 Tahun 2008 tentang Perbankan Syariah merupakan bukti pengakuan pemerintah bahwa pengaturan mengenai perbankan syariah yang selama ini ada belum secara spesik, sehingga perlu dirumuskan perundangan perbankan syariah secara khusus. Sejumlah perundangan memang telah disusun sebelumnya, yaitu UndangUndang Nomor 7 Tahun 1992 tentang Perbankan sebagaimana telah diubah dengan Undang-Undang Nomor 10 Tahun 1998. Undang-Undang Nomor 7 Tahun 1992 merupakan landasan bagi operasionalisasi perbankan syariah yang saat itu dianggap sebagai bank dengan sistem bagi hasil (prot and loss sharing) dan belum secara spesik sebagai perbankan dengan nilai-nilai syariah sebagai basis operasionalnya. ${ }^{1}$

Pertumbuhan dan perkembangan ekonomi syariah di Indonesia tidak hanya disektor bisnis financial atau perbankan, termasuk ragam dan jenis kegiatan ekonomi syariah mulai bermunculan seperti asuransi syariah, pegadaian syariah.

1 Yuli Adriansah, Kinerja Keuangan Perbankan Syariah di Indonesia dan Kontribusinya bagi Pembangunan Nasional, Jurnal Lariba, Vol. III, No. 2, Desember 2009, hlm 182
Dengan demikian ekonomi syariah telah menjadi bagian integral terhadap pembangunan ekonomi Indonesia yang terbukti mampu bertahan di tengah perekonomian dunia sedang mengalami gejolak. Karena itu sistem ekonomi syariah harus diperkuat di Indonesia. Demikian salah satu alasan Presiden Susilo Bambang Yudhoyono mencanangkan Gerakan Ekonomi Syariah (GRES!) di lapangan Monumen Nasional Jakarta, Minggu 17 September 2013. ${ }^{2}$

Secara objektif fakta juga menunjukkan komptensi perbankkan syariah menunjukkan hasil yang signifikan. Dari data yang ada perkembangan dana pihak ketiga di perbankan syariah juga menunjukkan peningkatan pada data yang ada. Dari sejumlah Rp2.918 Miliyar pada 2002, dana pihak ketiga naik menjadi Rp45.381 Miliyar pada September 2009. Setiap tahunnua, pertumbuhannya senantiasa positif bahkan mencapai $96,21 \%$ dan $107,20 \%$ pada 2003 dan 2004. Tingginya pertumbuhan pada dua tahun ini, patut

\footnotetext{
2 Adiwarman A. Karim, Perkembangan Ekonomi Syariah dan Potensi Sengketanya di Peradilan Agama, Majalah Peradilan Agama, Edisi 3, Des 2013-Feb 2014, Penerbit Dirjen Badilag MA-RI, 2013, hlm.5
} 
diduga merupakan buah dari Fatwa MUI tentang pengharaman bunga bank pada Desember 2003. Fatwa ini memang diharapkan pada saat tersebut mampu mendongkrak akselerasi perbankan syariah di Indonesia dan terbukti dampaknya pun dirasakan perbankan konvensional. Penelitian dengan model CAMEL Modied pada data dari Januari 2002 hingga Desember 2005 menunjukkan bahwa trend perkembangan kinerja keuangan perbankan nasional setelah fatwa MUI cenderung mengalami peningkatan. Enam dari tujuh rasio keuangan secara statistik menunjukkan perubahan yang signikan.18 Secara keseluruhan, dana pihak ketiga bahkan mampu tumbuh lebih dari $20 \%$ setiap tahunnya yang menunjukkan makin tingginya kepercayaan masyarakat terhadap pelaku industri ini. Hal ini sekaligus menjadikan tantangan bagi perbankan syariah untuk mampu meningkatkan kualitas pelayanan karena tuntutan persaingan yang lebih besar dari masa sebelumnya. ${ }^{3}$

$$
\text { Kondisi tersebut menjadi }
$$
pembuktian bahwa sistem perbankkan syariah memiliki nilai yang sangat jelas dalam mengusung sistem ekonomi nasional. Hal ini tentunya menjadi nilai tambah, akan tetapi disisi lain harus dibarengi dengan kebutuhan untuk memperkuat sistemnya. Salah satunya dalam hal model dan sistem penyelesaian sengketa.

Sudah 11 tahun berlalu, Pengadilan Agama diberikan kewenangan absolut untuk menangani perkara ekonomi syariah. Akan tidak menunjukkan adanya peningkatan volume perkara ekonomi syariah yang ditangani oleh Pengadilan Agama. Berdasarkan data statistik Perkara di Lingkungan Peradilan Agama tahun 2012, 21 laporan tahunan Peradilan Agama tahuntahun sebelumnya sampai dengan tahun 2006, dan dari Direktori Putusan Mahkamah Agung RI, jumlah perkara ekonomi syariah yang terdaftar di Pengadilan Agama sebanyak 35 perkara, 0, $00 \%$ dari jumlah perkara yang terdaftar di Pengadilan Agama 21 Direktorat Jenderal Badan Peradilan Agama Mahkamah Agung RI, Himpunan Statistik Perkara di Lingkungan Peradilan Agama Seluruh Indonesia, 2013. sejak tahun 2006 sampai dengan tahun 2013 tercatat sejumlah 2.196.217 perkara (Direktorat Jenderal Badan Peradilan Agama Mahkamah Agung RI, Himpunan Statistik Perkara di Lingkungan Peradilan Agama Seluruh Indonesia, 2013), sedangkan dari jumlah satker Pengadilan Agama seluruh Indonesia sebanyak 359 satker, baru hanya 16 atau 4, $5 \%$ Pengadilan Agama yang

${ }^{3}$ Yuli Adriansah, Opcit., 189 
pernah menangani sengketa ekonomi syariah. $^{4}$

\section{PEMBAHASAN}

Jika dilihat berdasarkan statistik di atas tentunya sangatlah sedikit. Padahal Pasal 49 huruf i Undang-Undang Nomor 3 Tahun 2006 Tentang Perubahan Atas Undang-Undang Nomor 7 Tahun 1989 Tentang Peradilan Agama, merupakan dasar hukum pelaksanaan ekonomi syariah. Sejak tanggal 20 Maret 2006 telah ada reformasi di bidang Peradilan Agama, seiring dengan upaya pemulihan Ekonomi nasional, perkembangan industri Ekonomi berprinsip Syari'ah. Eksistensi Bank Syari'ah semakin kuat dengan dibentuknya peraturan pemerintah yang mengatur Perbankan Syari'ah. Dasar hukum perbankan Syari'ah diatur dalam UndangUndang Nomor 21 Tahun 2008 Sesuai dengan Perbankan Nasional, setelah adanya undang-undang tersebut dualisme hukum mulai muncul. Sehingga Mahkamah Agung mengeluarkan Surat Edaran Mahkamah Agung Nomor 8 Tahun 2008 Tentang kewenangan Absolute mengadili dan eksekusi Putusan Badan Arbitrase Syariah Nasional dalam perkara sengketa ekonomi syari'ah menjadi kewenangan Pengadilan Agama 5

\footnotetext{
${ }^{4}$ Ahmad, Penyelesaian Sengketa Ekonomi Syariah Di Pengadilan Agama, Jurnal IUS | Vol II | Nomor 6 | Desember 2014, hlm 482

5 Ikhsan Al Hakim, Penyelesaian Sengketa Ekonomi Syariah Di Pengadilan Agama Purbalingga, Unnes Law Journal, 2 (2) (2013), hlm 218
}

Pengadilan Agama merupakan sebuah lembaga peradilan di lingkungan Peradilan Agama yang berkedudukan di ibu kota kabupaten atau kota. Sebagai Pengadilan Tingkat Pertama, Pengadilan Agama memiliki tugas dan wewenang untuk memeriksa, memutus, dan menyelesaikan perkara-perkara antara orang-orang yang beragama Islam di bidang: (a). Perkawinan; (b). Warisan, wasiat, dan hibah, yang dilakukan berdasarkan hukum Islam; (c). Wakaf dan shadaqah; (d). Ekonomi syari'ah. Kewenangan tersebut sesuai dengan Pasal 49 Undang-Undang Nomor 50 Tahun 2009 tentang Perubahan Kedua Atas UndangUndang Nomor 7 Tahun 1989 tentang Peradilan Agama.

Menurut Pasal 118 HIR, gugatan perdata pada tingkat pertama diajukan kepada ketua Pengadilan Agama yang daerah hukumnya meliputi : (1) Tempat tinggal Tergugat; (2) Jika tempat tinggal Tergugat tidak diketahui, maka di wilayah tempat diam Tergugat yang sebenarnya ; (3) Jika Tergugat lebih dari seorang, maka Penggugat boleh memilih salah satu dari domisili Tergugat ; (4) Jika ada debitur utama dan Penanggung, maka gugatan harus dimasukkan di domisili debitur utama ; (5) Jika gugatan itu tentang barang tetap, maka gugatan harus dimasukkan 
kepada Ketua Pengadilan Agama di daerah hokum siapa terletak barang itu ; (6) Jika ada pilihan domisili yang tertulis dalam akta, maka gugatan dimasukkan di tempat domisili yang dipilih itu. ${ }^{6}$

Namun dalam praktiknya secara kelembagaan berperkara ekonomi islam di pengadilan negeri menjadi pilihat favorit mengingat sistem pengadilan islam yang memiliki kompetensi tambahan yaitu sengketa perbankkan belum nampak dipahami secara serius sebagai sebuah alternatif yang tepat. Kondisi ini dilatar belakangi beberapa hal yang bisa kita analisas dari perspektif teori sistem hukum.

Lawrence M. Friedman menyebutkan bahwa sistem hukum itu terdiri atas komponen struktur, komponen substansi, dan komponen kultur.25 Komponen substansi berupa norma-norma dalam sistem hukum, sebagai output dari otoritas negara berupa peraturan maupun keputusan yang digunakan oleh pihak yang mengatur maupun yang diatur. Komponen struktur hukum yaitu kelembagan yang diciptakan oleh sistem hukum dengan berbagai macam fungsi dalam rangka bekerjanya suatu sistem hukum. Sedangkan komponen kultur berkaitan dengan nilai-nilai, sikap-sikap, persepsi,

${ }^{6}$ Hapsoro Hadiwidjojo, Hukum Acara Perdata, Membaca dan Mengerti HIR, (Semarang : FH UNDIP Press, 1983), hlm 3-5 opinion yang mempengaruhi bekerjanya suatu hukum.26 Berlakunya hukum dalam pemaknaan Soerjono Soekanto adalah efektivitas hukum, di mana membandingkan antara realitas hukum (das sein) dan ideal hukum (das sollen). ${ }^{7}$

Dalam konteks subtansi terdapat kelemahan meskipuan dalam Pasal 49 huruf i Undang-Undang Nomor 3 Tahun 2006 Tentang Perubahan Atas UndangUndang Nomor 7 Tahun 1989 Tentang Peradilan Agama, merupakan dasar hukum pelaksanaan ekonomi syariah. Sejak tanggal 20 Maret 2006 telah ada reformasi di bidang Peradilan Agama, seiring dengan upaya pemulihan Ekonomi nasional, perkembangan industri Ekonomi berprinsip Syari'ah. Eksistensi Bank Syari'ah semakin kuat dengan dibentuknya peraturan pemerintah yang mengatur Perbankan Syari'ah. Dasar hukum perbankan Syari'ah diatur dalam UndangUndang Nomor 21 Tahun 2008 Sesuai dengan Perbankan Nasional, setelah adanya undang-undang tersebut dualisme hukum mulai muncul. Sehingga Mahkamah Agung mengeluarkan Surat Edaran Mahkamah Agung Nomor 8 Tahun 2008 Tentang kewenangan Absolute mengadili dan eksekusi Putusan Badan Arbitrase Syariah Nasional dalam perkara

\footnotetext{
7 Lawrence M. Friedman, The Legal System: A Social Science Perspective (New York: Russel Sage Foundation, 1975), hlm. 16
} 
sengketa ekonomi syari'ah menjadi kewenangan Pengadilan Agama ${ }^{8}$.

Dalam hal ini kelemahan mengemuka pasca keluarnya UU No. 3/2006 tentang perubahan terhadap UU No. 7/1989 Tentang Peradilan Agama dimana Peradilan Agama kemudian diberi tambahan kewenangan untuk mengadili perkara sengketa ekonomi syari'ah sesuai dengan uraian di atas, Namun kewenangan untuk mengadili perkara ekonomi syariah, direduksi oleh Pasal 55 UU No. 21/2008 tentang Perbankan Syariah. Disebutkan dalam Pasal 55 ayat (1) Penyelesaian sengketa Perbankan Syariah dilakukan oleh pengadilan dalam lingkungan Peradilan Agama. Sementara pada Ayat (2) dikatakan "Dalam hal para pihak telah memperjanjikan penyelesaian sengketa selain sebagaimana dimaksud pada ayat (1), penyelesaian sengketa dilakukan sesuai dengan isi Akad. Hal ini memungkinkan terjadi benturan untuk menjalankan kewenangan yang sejatinya menjadi kewenangan pengadilan agama akan tetapi dalam hal para pihak menjadikan akad penyelesaian dilakukan di pengadilan negeri komptensi penyelesiaan sengketa di pengadalan agama terhadap masalah ekonomi islam menjagi gugur adanya.

8 Ikhsan Al Hakim, Penyelesaian Sengketa Ekonomi Syariah Di Pengadilan Agama Purbalingga, Unnes Law Journal, 2 (2) (2013), hlm 218
Dalam hal ini walapun Mahkamah Konstitusi telah membatalkan Pasal 55 ayat (2) Undang-Undang Nomor 21 Tahun 2008 tentang Perbankan Syariah, namun masih banyak peraturan yang masih perlu diharmonisasikan/sinkronisasikan terutama UU Kekuasaan Kehakiman, UU Alternatif Penyelesaian Sengketa, UU Perbankan Syari'ah pasca pergantian kekuasaan eksekutif dan legislatif. Pengharmonisasian dimaksud meliputi pengubahan peraturan perundangundangan yang berkaitan dengan perbankan syari'ah beserta penyelesaian sengketanya. Barangkali prinsip-prinsip modernisasi lembaga peradilan sengketa perdata di Ingris, Malaysia perlu diterapkan. Prinsip ini meliputi Doing the justice all together, cost efectively, democratically, efficiently, faster and doing it for government. Singkatnya, semua upaya itu dilakukan untuk kebaikan masyarakat, bangsa dan negara 9 .

Kompetensi dan kewenangan yang dimiliki oleh pengadilan agama dalam penengana ekonomi islam tidak

\footnotetext{
9 Refki fielnanda, Dualisme Penyelesaian Sengketa Ekonomi Syariah Yang Wajib Diatasi Oleh Presiden Baru, diunduh pada tanggal 12 Oktober 2017, pada situs dengan alamat https://refkyfielnanda.blogspot.co.id/2015/01/dualis me-penyelesaian-sengketa-ekonomi.html
} 
terlepas dari sejarah ummat islam pada masa ali bin abi thalib.

Dalam masa khalifah ali menurut arti bahasa, al Qadha berarti memutuskan atau menetapkan. Menurut istilah berarti "menetapkan hukum syara' pada suatu peristiwa atau sengketa

untuk menyelesaikannya secara adil dan mengikat". Adapun kewenangan yang dimiliki oleh lembaga ini adalah menyelesaikan perkaraperkara tertentu yang berhubungan dengan masalah al ahwal asy syakhsiyah (masalah keperdataan, termasuk didalamnya hukum keluarga), dan masalah jinayat (yakni hal-hal yang menyangkut pidana). Orang yang diberi wewenang menyelesaikan perkara di Pengadilan disebut dengan qadhi (hakim). Dalam catatan sejarah Islam, seorang yang pernah menjadi qadhi (hakim) yang cukup lama adalah al Qadhi Syureih. Beliau memangku jabatan hakim selama dua periode sejarah, yakni pada masa penghujung

pemerintah

Khulafaurrasyidin (masa Khalifah Ali Ibn Abi Thalib) dan masa awal dari pemerintahan Bani Umayyah. Di samping tugas-tugas menyelesaikan perkara, para hakim pada pemerintahan Bani Umayyah juga diberi tugas tambahan yang bukan berupa penyelesaian perkara, misalnya menikahkan wanita yang tidak punya wali, pengawasan baitul mall dan mengangkat pengawas anak yatim $^{10}$.

Komptensi pengawasan baitull mall menjadi kewenangan mutlak pengadilan dalam memperjuangkan keadilan. Hal teresbut selaras dengan Pasal 49 huruf i Undang-Undang Nomor 3 Tahun 2006 Tentang Perubahan Atas Undang-Undang Nomor 7 Tahun 1989 Tentang Peradilan Agama, merupakan dasar hukum pelaksanaan ekonomi syariah.

Kebutuhan yang kedua dalam memperkuat penyelesaian ekonomi islam adalah kebutuhan memperkuat bidang struktural. Kebutuhan memperkuat bidang struktural merupkan langkah dan wujud strategis dalam mewujudkan sebuah tatanan sistem penyelesaian yang akuntabel dan berbasiskan pada aspekaspek kepastian hukum. Diantaranya selaian peningkatan Sumber daya mansuia hakim harus memhami pengaturanpengaturan tentang perbankkan syariah dan hal-hal yang berkaitan dengan

\footnotetext{
10 Abdul Manan, penyelesaian sengketa ekonomi syariah ; Sebuah kewenangan baru peradilan agama, makalah Disampaikan pada acara Orientasi Penyelesaian Sengketa Ekonomi Syariah pada hari Jum'at, tanggal 29 s/d 31 Mei 2008 di Goodway Hotel, Jl. Imam Bonjol No. 1 Nagoya Batam Island
} 
pengaturannya. Banyak sekali aturan hukum yang terdapat dalam berbagai peraturan perundang-undangan yang mempunyai titik singgung dengan Undang-Undang Nomor 3 Tahun 2006 ini. Oleh karena itu Hakim Peradilan Agama harus mempelajari dan memahaminya untuk dijadikan pedoman dalam memutuskan perkara ekonomi syari'ah.

Di antara peraturan perundangundangan yang harus dipahami oleh Hakim Peradilan Agama yang berhubungan dengan Bank Indonesia antara lain :

1. Undang-Undang Nomor 7 Tahun 1992 Tentang Perbankan.

2. Undang-Undang Nomor 10 Tahun 1998 Tentang Perubahan atas Undang-Undang Nomor 7 Tahun 1992 tentang Perbankan.

3. Peraturan BI No. 6/24/PBI/2004 tentang Bank Umum yang melaksanakan Kegiatan Usaha Berdasarkan Prinsip Syari'ah.

4. Peraturan BI No. 6/9/PBI/DPM Tahun 2004 tentang Penyisihan Penghapusan Aktiva Produktif bagi Bank Perkreditan Rakyat Syari'ah.

5. Peraturan BI No. 3/9/PBI/2003 tentang Penyisihan Penghapusan Aktiva Produktif bagi Bank Syari'ah.

6. Surat Edaran BI No. 6/9/DPM Tahun 2004 tentang Tata Cara Pemberian Fasilitas Pembiayaan Jangka Pendek bagi Bank Syari'ah.

7. Surat Keputusan Direksi Bank Indonesia Nomor 32/34/Kep/Dir tentang Bank Umum Berdasarkan Prinsip Syari'ah.
8. Surat Keputusan Direksi Bank Indonesia Nomor 32/36/Kep/Dir tentang Bank Perkreditan Rakyat Berdasarkan Prinsip Syari'ah.

9. Surat Keputusan Direksi Bank Indonesia Nomor 21/53/Kep/Dir./1988 tanggal 27 Oktober 1988 tentang Surat Berharga Pasar Uang (SBPU).

10. Surat Keputusan Direksi Bank Indonesia Nomor 21/48/Kep/Dir./1988 dan Surat Edaran Bank Indonesia Nomor 21/27/UPG tanggal 27 Oktober 1988 tentang Sertifkat Deposito.

11. Surat Edaran Bank Indonesia Nomor 28/32/UPG tanggal 4 Juli 1995 Jo. Surat Keputusan Direksi Bank Indonesia Nomor 28/32/Kep/Dir. tertanggal 4 Juli 1995 tentang Bilyet Giro.

12. Surat Keputusan Direksi Bank Indonesia Nomor 31/67/Kep/Dir. tertanggal 23 Juli 1998 tentang sertifikat Bank Indonesia.

13. Surat Edaran Bank Indonesia Nomor 28/49/UPG tertanggal 11 Agustus 1995 tentang Persyaratan Penerbitan dan Perdagangan Surat Berharga Komersial (Commercial Paper).

14. Surat Edaran Bank Indonesia Nomor 23/5/UKU tanggal 28 Februari 1991 tentang Pemberian Garansi Bank.

Selian itu, beberapa pengaturan yang perlu untuk dikuatkan dan dipahami oleh hakim diantaranya peraturan perundang-undangan yang lain yang mempunyai persentuhan dengan UndangUndang Nomor 3 Tahun 2003 tentang Peradilan Agama, antara lain : 
1. Undang-Undang Nomor 5 Tahun 1960 tentang Agraria.

2. Undang-Undang Nomor 6 Tahun 1969 Tentang BUMN.

3. Undang-Undang Nomor 3 Tahun 1982, tentang Wajib Daftar Perusahaan.

4. Undang-Undang Nomor 2 Tahun 1992, tentang Usaha Perasuransian.

5. Undang-Undang Nomor 25 Tahun 1992, tentang Perkoperasian.

6. Undang-Undang Nomor 8 Tahun 1987, tentang Dokumen Perusahaan.

7. Undang-Undang Nomor 1 Tahun 1995, tentang Perusahaan Terbatas.

8. Undang-Undang Nomor 1 Tahun 1998, tentang Kepailitan.

9. Undang-Undang Nomor 4 Tahun 1996, tentang Hak Tanggungan atas Tanah beserta Benda-benda yang berkaitan dengan tanah.

10. Undang-Undang Nomor 8 Tahun 1995, tentang Pasar Modal.

11. Undang-Undang Nomor 4 Tahun 1996, tentang Hak Tanggungan Atas Tanah beserta Benda-benda yang Berkaitan dengan Tanah.

12. Undang-Undang Nomor 5 Tahun 1999, tentang Antimonopoli dan Persaingan Tidak Sehat.

13. Undang-Undang Nomor 8 Tahun 1999, tentang Perlindungan

Konsumen.

14. Undang-Undang Nomor 30 Tahun 1999, tentang Arbitrase dan Alternatif Penyelesaian Sengketa.

15. Undang-Undang Nomor 41 Tahun 2004, tentang Wakaf.

16. Undang-Undang Nomor 38 Tahun 1999, tentang Zakat.

17. Undang-Undang Nomor 42 Tahun 1999, tentang Fidusia.

18. Undang-Undang Nomor 31 Tahun 2000, tentang Desain Industri.
19. Undang-Undang Nomor 14 Tahun 2001, tentang Paten.

20. Undang-Undang Nomor 15 Tahun 2001, tentang Merek.

21. Undang-Undang Nomor 16 Tahun 2001, tentang Yayasan.

22. Undang-Undang Nomor 19 Tahun 2002, tentang Hak Cipta.

23. Peraturan Pemerintah Nomor 28 Tahun 1977, tentang Wakaf Tanah Milik.

24. Peraturan Pemerintah Nomor 24 Tahun 1997, tentang Pendaftaran Tanah.

25. Peraturan Pemerintah Nomor 12 Tahun 1998, tentang Perusahaan Terbatas (Perseroan).

26. Peraturan Pemerintah Nomor 13 Tahun 1998, tentang Perusahaan Umum (Perum).

27. Peraturan Pemerintah Nomor 45 Tahun 1995, tentang Penyelenggaraan Kegiatan dibidang Pasar Modal.

28. Peraturan Pemerintah Nomor 40 Tahun 1996, tentang Hak Guna Usaha. Hak Guna Bangunan dan Hak Pakai Atas Tanah.

29. Peraturan Presiden Republik Indonesia Nomor 19 Tahun 2005, tentang Pembiayaan Sekunder Perumahan.

30. Peraturan Presiden Republik Indonesia Nomor 36 Tahun 2005, tentang Pengadaan Tanah Bagi Pelaksanaan Pembangunan Untuk Kepentingan Umum.

31. Keputusan Presiden Nomor 37 Tahun 1999 tentang Badan Koordinasi Penanaman Modal.

32. Keputusan Presiden Nomor 34 Tahun 2003 Tentang Kebijakan Nasional di Bidang Pertanahan.

33. Keputusan Menteri Negara Investasi/Kepala Badan Koordinasi 
Penanaman Modal Nomor

38/SK/1999 tentang Pedoman dan

Tata Cara Permohonan Penanaman

Modal Dalam Negeri dan Penanaman

Modal Asing.

34. Keputusan Bersama Menteri Pertanian dan Kepala Badan Pertanahan

Nasional Nomor

515/Kpts/HK.060/9/2004 Nomor

2/SKB/BPN/2004.

35. Keputusan Bersama Menteri Agama dan Kepala Badan Pertanahan

Nasional Nomor 422 Tahun 2004,

Nomor 3/SKB/BPN/2004 tentang

Sertifikasi Tanah Wakaf.

Disamping itu, beberapa

ketentuan terkait fatwa MUI juga perlu dipahami hakim pengadilan agama sebagai penguatan sistem penyelesain sengketa dipengadilan agama. Sampai saat ini kurang lebihnya telah ada 61 fatwa tentang kegiatan ekonomi syari'ah yang diantaranya sebagai berikut :

1. Fatwa Dewan Syari'ah Nasional No. 01/DSN-MUI/IV/2006 Tentang Giro.

2. Fatwa Dewan Syari'ah Nasional No. 02/DSN-MUI/IV/2006 Tentang Tabungan.

3. Fatwa Dewan Syari'ah Nasional No. 03/DSN-MUI/IV/2006 Tentang Deposito.

4. Fatwa Dewan Syari'ah Nasional No. 04/DSN-MUI/IV/2006 Tentang Murabahah.

5. Fatwa Dewan Syari'ah Nasional No. 05/DSN-MUI/IV/2006 Tentang Jual Beli Saham.

6. Fatwa Dewan Syari'ah Nasional No. 06/DSN-MUI/IV/2006 Tentang Jual Beli Istishna'.
7. Fatwa Dewan Syari'ah Nasional No. 07/DSN-MUI/IV/2006 Tentang Pembiayaan Mudharabah (Qiradh).

8. Fatwa Dewan Syari'ah Nasional No. 08/DSN-MUI/IV/2006 Tentang Pembiayaan Musyarakah.

9. Fatwa Dewan Syari'ah Nasional No. 09/DSN-MUI/IV/2006 Tentang Pembiayaan Ijarah.

10. Fatwa Dewan Syari'ah Nasional No. 10/DSN-MUI/IV/2006 Tentang Wakalah.

11. Fatwa Dewan Syari'ah Nasional No. 11/DSN-MUI/IV/2006 Tentang Kafalah.

12. Fatwa Dewan Syari'ah Nasional No. 12/DSN-MUI/IV/2006 Tentang Hawalah.

13. Fatwa Dewan Syari'ah Nasional No. 13/DSN-MUI/IV/2006 Tentang Uang Muka dalam Murabahah.

14. Fatwa Dewan Syari'ah Nasional No. 14/DSN-MUI/IV/2006 Tentang Sistem Distribusi Hasil Usaha dalam Lembaga Keuangan Syari'ah.

15. Fatwa Dewan Syari'ah Nasional No. 15/DSN-MUI/IV/2006 Tentang Prinsip Distribusi Hasil Usaha dalam Lembaga Keuangan Syari'ah.

16. Fatwa Dewan Syari'ah Nasional No. 16/DSN-MUI/IV/2006 Tentang Diskon dalam Murabahah.

17. Fatwa Dewan Syari'ah Nasional No. 17/DSN-MUI/IV/2006 Tentang Sanksi atas Nasabah Mampu yang Menunda-nunda Pembayaran.

18. Fatwa Dewan Syari'ah Nasional No. 18/DSN-MUI/IV/2006 Tentang Pencadangan Pengahapusan Aktiva Produktif dalam Lembaga Keuangan Syari'ah.

19. Fatwa Dewan Syari'ah Nasional No. 19/DSN-MUI/IV/2006 Tentang al Qardh. 
20. Fatwa Dewan Syari'ah Nasional No. 20/DSN-MUI/IV/2006 Tentang

Pedoman Pelaksanaan Investasi untuk Reksa Dana Syari'ah.

21. Fatwa Dewan Syari'ah Nasional No. 21/DSN-MUI/IV/2006 Tentang Pedoman Umum Asuransi Syari'ah.

22. Fatwa Dewan Syari'ah Nasional No. 22/DSN-MUI/IV/2006 Tentang Jual Beli Istishna' Pararel.

23. Fatwa Dewan Syari'ah Nasional No. 23/DSN-MUI/IV/2006 Tentang

Potongan Pelunasan dalam Murabahah.

24. Fatwa Dewan Syari'ah Nasional No. 24/DSN-MUI/IV/2006 Tentang Safe Defosit Box.

25. Fatwa Dewan Syari'ah Nasional No. 25/DSN-MUI/IV/2006 Tentang Rahn.

26. Fatwa Dewan Syari'ah Nasional No. 26/DSN-MUI/IV/2006 Tentang RAHN Emas.

27. Fatwa Dewan Syari'ah Nasional No. 27/DSN-MUI/IV/2006 Tentang al Ijarah al Muntahiyah Bi al Tamlik.

28. Fatwa Dewan Syari'ah Nasional No. 28/DSN-MUI/IV/2006 Tentang Jual Beli Mata Uang (al Sharf).

29. Fatwa Dewan Syari'ah Nasional No. 29/DSN-MUI/IV/2006 Tentang Pembiayaan Pengurusan Haji Lembaga Keuangan Syari'ah.

30. Fatwa Dewan Syari'ah Nasional No. 30/DSN-MUI/IV/2006 Tentang Pembiayaan Rekening Koran Syari'ah.

31. Fatwa Dewan Syari'ah Nasional No. 31/DSN-MUI/IV/2006 Tentang Pengalihan Hutang.

32. Fatwa Dewan Syari'ah Nasional No. 32/DSN-MUI/IV/2006 Tentang Obligasi Syari'ah.
33. Fatwa Dewan Syari'ah Nasional No. 33/DSN-MUI/IV/2006 Tentang Obiligasi Syari'ah Mudharabah.

34. Fatwa Dewan Syari'ah Nasional No. 34/DSN-MUI/IV/2006 Tentang Letter of Credit $(L / C)$ Impor Syari'ah.

35. Fatwa Dewan Syari'ah Nasional No. 35/DSN-MUI/IV/2006 Tentang Letter of Credit $(L / C)$ Ekspor Syari'ah.

36. Fatwa Dewan Syari'ah Nasional No. 36/DSN-MUI/IV/2006 Tentang Sertifikat Wadi'ah Bank Indonesia (SWBI).

37. Fatwa Dewan Syari'ah Nasional No. 37/DSN-MUI/IV/2006 Tentang Pasar Uang Antar Bank Berdasarkan Prinsip Syari'ah.

38. Fatwa Dewan Syari'ah Nasional No. 38/DSN-MUI/IV/2006 Tentang Sertifikat Investasi Mudharabah Antar Bank (Sertifkat IMA).

39. Fatwa Dewan Syari'ah Nasional No. 39/DSN-MUI/IV/2006 Tentang Asuransi Haji.

40. Fatwa Dewan Syari'ah Nasional No. 40/DSN-MUI/IV/2006 Tentang Pasar Modal dan Pedoman Umum Penerapan Prinsip Syari'ah di Bidang Pasar Modal.

41. Fatwa Dewan Syari'ah Nasional No. 41/DSN-MUI/IV/2006 Tentang Obligasi Syari'ah Ijarah.

42. Fatwa Dewan Syari'ah Nasional No. 42/DSN-MUI/IV/2006 Tentang Syari'ah Charge Card.

43. Fatwa Dewan Syari'ah Nasional No. 43/DSN-MUI/IV/2006 Tentang Ganti Rugi (Ta'widh).

44. Fatwa Dewan Syari'ah Nasional No. 44/DSN-MUI/IV/2006 Tentang Pembiayaan Multijasa.

45. Fatwa Dewan Syari'ah Nasional No. 45/DSN-MUI/IV/2006 Tentang Line Facility (at-Tashilat). 
46. Fatwa Dewan Syari'ah Nasional No. 46/DSN-MUI/IV/2006 Tentang Potongan Tagihan Murabahah (al Khas, Fi al Murabahah).

47. Fatwa Dewan Syari'ah Nasional No. 47/DSN-MUI/IV/2006 Tentang Penyelesaian Piutang Murabahah Bagi Nasabah Tidak Mampu Membayar.

48. Fatwa Dewan Syari'ah Nasional No. 48/DSN-MUI/IV/2006 Tentang Penjadwalan Kembali Tagihan Murabahah.

49. Fatwa Dewan Syari'ah Nasional No. 49/DSN-MUI/IV/2006 Tentang Konversi Akad Murabahah.

50. Fatwa Dewan Syari'ah Nasional No. 50/DSN-MUI/IV/2006 Tentang Akad Mudharabah Musyarakah.

51. Fatwa Dewan Syari'ah Nasional No. 51/DSN-MUI/IV/2006 Tentang Akad Mudharabah Musyarakah Pada Asuransi Syari'ah.

52. Fatwa Dewan Syari'ah Nasional No. 52/DSN-MUI/IV/2006 Tentang Akad Wakalah Bil Ujrah Pada Asuransi dan Reasuransi Syari'ah.

53. Fatwa Dewan Syari'ah Nasional No. 53/DSN-MUI/IV/2006 Tentang Adab Tabarru' Pada Asuransi dan Reasuransi Syari'ah.

54. Fatwa Dewan Syari'ah Nasional No. 54/DSN-MUI/X/2006 Tentang Card.

55. Fatwa Dewan Syari'ah Nasional No. 55/DSN-MUI/V/2007 Tentang Pembiayaan Rekening Koran Syari'ah Musyarakah.

56. Fatwa Dewan Syari'ah Nasional No. 56/DSN-MUI/V/2007 Tentang Ketentuan Review Ujrah Pada Lembaga Keuangan Syari'ah.

57. Fatwa Dewan Syari'ah Nasional No. 57/DSN-MUI/V/2007 Tentang Letter of Credit (LC) Dengan Akad Kafalah Bil Ujrah.

58. Fatwa Dewan Syari'ah Nasional No. 58/DSN-MUI/V/2007 Tentang Hawalah Bil Ujrah.

59. Fatwa Dewan Syari'ah Nasional No. 59/DSN-MUI/V/2007 Tentang Obligasi Syari'ah Mudharabah Konvensi.

60. Fatwa Dewan Syari'ah Nasional No. 60/DSN-MUI/V/2007 Tentang Penyelesaian Piutang dalam Ekspor.

61. Fatwa Dewan Syari'ah Nasional No. 61/DSN-MUI/V/2007 Tentang

Penyelesaian Piutang dalam Impor.

Disamping penguatan kelembagaan melalui peningkatan kapasitas Sumber daya manusia,upaya yang perlu dilakukan adalah melalui penyadaran masyarakat. Masyarakat dalam hal ini baik pengguna jasa perbankkan syariah maupun perbankkan syariah sendiri.

Budaya hukum lebih mengarah pada sikap masyarakat, kepercayaan masyarakat, nilai-nilai yang dianut masyarakat dan ide-ide atau pengharapan mereka terhadap hukum dan sistem hukum. Dalam hal ini kultur hukum merupakan gambaran dari sikap dan perilaku terhadap hukum, serta keseluruhan faktor-faktor yang menentukan bagaimana sistem hukum memperoleh tempat yang sesuai dan dapat diterima oleh warga masyarakat dalam kerangka budaya masyarakat. Semakin tinggi kesadaran hukum masyarakat, maka akan tercipta budaya hukum yang baik dan 
dapat merubah pola pikir masyarakat selama ini. ${ }^{11}$

\section{KESIMPULAN}

Berdasarkan uraian pembahasan di atas, kesimpulan yang dapat diambil sebagai berikut :

Meskipun Mahkamah Konstitusi telah membatalkan Pasal 55 ayat (2) Undang-Undang Nomor 21 Tahun 2008 tentang Perbankan Syariah, namun masih banyak peraturan yang masih perlu diharmonisasikan/sinkronisasikan terutama UU Kekuasaan Kehakiman, UU Alternatif Penyelesaian Sengketa, UU Perbankan Syari'ah pasca pergantian kekuasaan eksekutif dan legislatif. Penguatan regulais ini sangatlah penting dan strategis dalam menjadikan penyelesaian sengketa ekonomi islam di pengadilan agama memiliki nilai kepastian hukum

Kebutuhan yang kedua dalam memperkuat penyelesaian ekonomi islam adalah kebutuhan memperkuat bidang struktural. Kebutuhan memperkuat bidang struktural merupkan langkah dan wujud strategis dalam mewujudkan sebuah tatanan sistem penyelesaian yang akuntabel dan berbasiskan pada aspekaspek kepastian hukum. Diantaranya

11 Sistem hukum menurut lawrent friedment, diunduh tanggal 20 -10-2017 pada situs yang beralamat https:/fidianurulmaulidah.wordpress.com/2014/05/ 18/sistem-hukum-menurut-laurence-m-friedman/ selaian peningkatan Sumber daya mansuia hakim harus memhami pengaturanpengaturan tentang perbankkan syariah dan hal-hal yang berkaitan dengan pengaturannya. Banyak sekali aturan hukum yang terdapat dalam berbagai peraturan perundang-undangan yang mempunyai titik singgung dengan Undang-Undang Nomor 3 Tahun 2006 ini. Oleh karena itu Hakim Peradilan Agama harus mempelajari dan memahaminya untuk dijadikan pedoman dalam memutuskan perkara ekonomi syari'ah.

Disamping

penguatan

kelembagaan melalui peningkatan kapasitas Sumber daya manusia,upaya yang perlu dilakukan adalah melalui penyadaran masyarakat. Masyarakat dalam hal ini baik pengguna jasa perbankkan syariah maupun perbankkan syariah sendiri. Budaya hukum lebih mengarah pada sikap masyarakat, kepercayaan masyarakat, nilai-nilai yang dianut masyarakat dan ide-ide atau pengharapan mereka terhadap hukum dan sistem hukum. Dalam hal ini kultur hukum merupakan gambaran dari sikap dan perilaku terhadap hukum, serta keseluruhan faktor-faktor yang menentukan bagaimana sistem hukum memperoleh tempat yang sesuai dan dapat diterima oleh warga masyarakat dalam kerangka budaya masyarakat

Daftar Pustaka 
Adiwarman A. Karim, Perkembangan

Ekonomi Syariah dan Potensi Sengketanya di Peradilan Agama, Majalah Peradilan Agama, Edisi 3, Des 2013-Feb 2014, Penerbit Dirjen Badilag MA-RI, 2013

Ahmad, Penyelesaian Sengketa Ekonomi Syariah Di Pengadilan Agama, Jurnal IUS | Vol II | Nomor 6 | Desember 2014

Hapsoro Hadiwidjojo, Hukum Acara Perdata, Membaca dan Mengerti HIR, (Semarang : FH UNDIP Press, 1983)

Ikhsan Al Hakim, Penyelesaian Sengketa Ekonomi Syariah Di Pengadilan Agama Purbalingga, Unnes Law Journal, 2 (2) (2013)

Ikhsan Al Hakim, Penyelesaian Sengketa Ekonomi Syariah Di Pengadilan Agama Purbalingga, Unnes Law Journal, 2 (2) (2013)

Lawrence M. Friedman, The Legal System: A Social Science Perspective (New York: Russel Sage Foundation, 1975)

\section{Jurnal}

Yuli Adriansah, Kinerja Keuangan Perbankan Syariah di Indonesia dan Kontribusinya bagi Pembangunan Nasional, Jurnal Lariba, Vol. III, No. 2, Desember Makalah 2009

Abdul Manan, penyelesaian sengketa ekonomi syariah ; Sebuah kewenangan baru peradilan agama, makalah Disampaikan pada acara Orientasi Penyelesaian Sengketa Ekonomi Syariah pada hari Jum'at, tanggal 29 s/d 31 Mei 2008 di Goodway Hotel, Jl. Imam Bonjol No. 1 Nagoya Batam Island

\section{Internet}

Refki fielnanda, Dualisme Penyelesaian Sengketa Ekonomi Syariah Yang Wajib Diatasi Oleh Presiden Baru, diunduh pada tanggal 12 Oktober 2017, pada situs dengan alamat

https://refkyfielnanda.blogspot.co. id/2015/01/dualismepenyelesaian-sengketaekonomi.html

Sistem hukum menurut lawrent friedment, diunduh tanggal $20 \quad-10-2017$ pada situs yang beralamat di https://fidianurulmaulidah.wordpr ess.com/2014/05/18/sistemhukum-menurut-laurence-mfriedman/ 